\title{
EVALUASI KANDUNGAN BAHAN KERING, BAHAN ORGANIK DAN PROTEIN KASAR PELEPAH SAWIT FERMENTASI DENGAN PENAMBAHAN SUMBER KARBOHIDRAT
}

\author{
T. ASTUTI1., M. N. ROFIQ ${ }^{2}$ DAN NURHAITA ${ }^{3}$ \\ Universitas Mahaputra Muhammad Yamin'1, BPPT Serpong ${ }^{2}$,Universitas Muhammadiyah Bengkulu \\ Email :adektuti@gmail.com
}

\begin{abstract}
This research aimed to evaluate the useful of palm oil fronds as feed substitution of grass. The feeding have enhanced the quality through fermented biotechnology innovations with the addition of soluble carbohydrates. The complete randomized design of $2 \times 3$ factorial pattern with 3 replications for each treatment have used as experimental design. Factor $A$ was the source of fermentation inoculum; $A 1=$. Local microorganism of rumen contents, $A 2=$ Lactobacillus bacteria. Factor $B$ was the source of soluble carbohydrate; $B 1=$ no carbohydrate source, $B 2=$ rice bran, $B 3=$ tapioca flour. The parameters was the content of dry matter, organic matter, and crude protein. The resulted of this research shown that no interaction effect between the source of microorganism with the carbohydrate, and no effect the treatment on the dry matter $(P>0.05)$. Meanwhile the factor $B$ was significant effect $(P<00.1)$ on the organic matter and crude protein. The highest crude protein on the fermented palm oil frond by adding the rice brain as soluble carbohydrate.
\end{abstract}

Keywords : palm oil frond, fermented, the source of carbohydrate

\section{PENDAHULUAN}

Luas perkebunan sawit di Indonesia pada tahun 2013 adalah 6.170.700 Ha dan untuk daerah provinsi Jambi pada tahun 2014 sekitar 657.930 Ha (BPS, 2015). Perkebunan kelapa sawit selain memberikan manfaat dari hasil produksi dan olahannya untuk memenuhi kebutuhan pangan juga tersedia limbah yang sangat banyak baik dari segi jumlah maupun jenisnya, baik dari limbah perkebunan maupun limbah dari pengolahan pabriknya.

Pelepah dan daun kelapa sawit merupakan limbah padat perkebunan kelapa sawit yang memiliki potensi untuk digunakan sebagai pakan basal ternak ruminansia. Pemanfaatan limbah perkebunan sebagai bahan pakan selalu terkendala dengan adanya ikatan ligno selulosa yang biasanya mempunyai kandungan lignin yang tinggi. Kandungan lignin pelepah sawit 15,35\% (Astuti dkk., 2014) dan adanya kandungan tanin yang tinggi dan komponen fenolik (Jaffri et al., 2011) sehingga membutuhkan sentuhan teknologi sebelum dimanfaatkan sebagai pakan. Perlakuan bahan pakan melalui pendekatan bioteknologi fermentasi dianggap lebih mudah, murah dan ramah lingkungan dibandingankan dengan perlakuan secara kimia.

Wina (2005) menyatakan pemberian pakan yang berkualitas rendah dengan kandungan lignin yang tinggi, akan menyebabkan kondisi dan fungsi rumen kurang baik, sehingga diperlukan teknologi untuk memperbaikinya. Fermentasi merupakan salah satu teknologi untuk meningkatkan kualitas pakan asal limbah, karena keterlibatan mikroorganisme dalam mendegradasi serat kasar, mengurangi kadar lignin dan senyawa anti nutrisi, sehingga nilai kecernaan pakan asal limbah dapat meningkat.

Hasil penelitian Biyatmoko (2013) fermentasi pelepah sawit menggunakan jenis-jenis inokulum yang berbeda menunjukkan hasil peningkatan protein (PK) pelepah sawit fermentasi secara signifikan dari 2,11\% (kontrol) menjadi 2,41\% (inokulum EM-4). Hasil penelitian Astuti (2012) yang menggunakan sumber 
Mikroorganisme Lokal (MOL) dari beberapa bahan terbuang (isi rumen, kulit pisang dan limbah sayuran) sebagai inokulum untuk memfermentasi kulit pisang dan hasil fermentasi yang optimal didapatkan dari sumber MOL isi rumen. Hasil penelitian Astuti et al. (2016) melakukan isolasi dan uji morfologi pada beberapa mikroorganisme lokal dan mendapatkan 8 bakteri thermophilic gram positif. Simanihuruk et al. (2008) menyatakan keberhasilan proses fermentasi dapat berjalan dengan baik bila tersedia karbohidrat terlarut yang cukup. Kandungan gula bahan merupakan energi penting bagi pengembangan kapang selama proses fermentasi.

Penambahan berbagai sumber karbohidrat terlarut pada substrat pelepah sawit yang difermentasi menggunakan kapang Aspergillus niger dapat meningkatkan kandungan protein kasar pada semua perlakuan, namun belum optimal dalam menurunkan kandungan serat kasar substrat.

Penambahan tepung sagu dan dedak halus dapat meningkatkan nilai KCBK dan KCBO seiring dengan meningkatnya VFA total sebagai indikator kualitas pakan (Wajizah, 2015). Tepung tapioka yang merupakan umbi ketela pohon yang sudah dihaluskan dan dikeringkan mempunyai kandungan karbohidrat sekitar 86,9\% (Badan Ketahanan Pangan dan Penyuluhan Provinsi DIY, 2012).

Dedak padi adalah hasil samping pada pabrik penggilingan padi dalam memproduksi beras, yang merupakan bagian kulit ari beras pada waktu dilakukan proses pemutihan beras. Menurut National Research Council (1994) dedak padi mengandung energy metabolis sebesar $2980 \mathrm{kkal} / \mathrm{kg}$, protein kasar $12,9 \%$; lemak $13 \%$; serat kasar $11,4 \%$; Ca $0,07 \%$; P tersedia $0,22 \%$; Mg 0,95\% serta kadar air (Dewan Standarisasi Nasional, 2001).
Berdasarkan hal tersebut di atas penelitian ini dilakukan dengan tujuan untuk melakukan evaluasi kandungan bahan kering, bahan organik dan kandungan protein kasar pelepah sawit yang difermentasi dengan sumber mikroorganisme dan sumber karbohidrat yang berbeda.

\section{MATERI DAN METODE}

\section{Tempat dan Waktu Pelaksanaan}

Penelitian ini dilaksanakan di Laboratorium Badan Pengkajian dan Penerapan Teknologi (BPPT) Serpong pada tahun 2016.

\section{MateriPenelitian}

Materi yang digunakan dalam penelitian ini terdiri dari pelepah sawit yang diperoleh di daerah sekitar kampus. Lactobacillus sp didapatkan dari laboratorium ternak perah Institut Pertanian Bogor (IPB), sedangkan mikroorganisme lokal didapatkan dari hasil inkubasi isi rumen yang berasal dari rumah pemotongan hewan Kabupaten Bungo yang digunakan sebagai starter dalam proses fermentasi. Sebagai sumber karbohidrat terlarut yang ditambahkan pada media fermentasi dalam penelitian ini digunakan dedak dan tepung tapioka.

\section{Bahan dan Alat yang Digunakan}

Bahan-bahan yang digunakan dalam penelitian yaitu pelepah sawit, starter lactobacillus sp, mikroorganisme lokal isi rumen, dedak, tepung tapioka dan aquades.

Alat-alat yang digunakan dalam penelitian ini meliputi parang, baskom, timbangan digital, gelas ukur, baki plastik, pengaduk, sendok, sprayer, oven, autoclave, sarung tangan, wrapping plastic, plastik anti panas, alat penggiling (mortel, blender) dan masker. 


\section{Prosedur Penelitian}

Pelepah sawit sebagai sampel pada penelitian ini merupakan hasil sampingan perkebunan sawit, dihaluskan dengan menggunakan mesin chopper. Setelah halus sampel sebanyak $300 \mathrm{~g} /$ unit perlakuan yang dimasukkan ke dalam kantong plastik dicampurkan dengan sumber mikroorganisme MOL isi rumen dan lactobacillus yang sudah diencerkan terlebih dahulu, selanjutnya diaduk hingga homogen dan ditambahkan tepung tapioka dan dedak sebanyak $10 \%$ menurut perlakuan masing-masing dari bahan kering. Kantong plastik yang berisi substrat dipadatkan dan diikat hingga kedap udara, kemudian difermentasi selama 7 hari. Setelah fermentasi berakhir, sampel dikeringkan dalam oven pada suhu $60^{\circ} \mathrm{C}$. Selanjutnya sampel dianalisis kandungan bahan kering, protein kasar, serat kasar dan abu (AOAC, 1995).

\section{Pembuatan Larutan Mikroorganisme Lokal}

Masing-masing sumber mikro organisme lokal dari isi rumen, feses sapi, dan urin sapi dicampur dengan air kelapa dengan perbandingan 1:4 dan gula sebanyak $1 \mathrm{~kg}$ di dalam stoples. Tutup rapat stoples dan dilobangi di tengahnya dan dihubungkan dengan slang kecil dengan botol yang berisi aquades, kemudian difermentasi selama 10 hari (Astuti dkk., 2014).

\section{Rancangan Penelitian}

Penelitian ini menggunakan Rancangan Acak Lengkap dengan pola Faktorial 2 X 3 dengan 3 ulangan

Faktor A adalah sumber mikroorganisme $\mathrm{A} 1=\mathrm{MOL}$ isi rumen A2 = Lactobacilus
Faktor B adalah karbohidrat solubel

B1 = tanpa karbohidrat solubel

B2 = dedak padi

$\mathrm{B} 3=$ tepung tapioka

\section{HASIL DAN PEMBAHASAN}

\section{Kandungan Bahan Kering}

Berdasarkan analisis keragaman menujukkan tidak terdapat interaksi $(\mathrm{P}>0,05)$ antara perlakuan fermentasi sumber mikroorganisme (lactobaccillus $s p$, MOL isi rumen) dengan sumber karbohidrat soluble (dedak, tapioka) dan masing-masing perlakuan tidak berpengaruh $(\mathrm{P}>0,05)$ terhadap kandungan bahan kering. Hasil penelitian ini menunjukkan fermentasi pelepah sawit dengan lactobacillus $s p$ ataupun menggunakan MOL isi rumen tidak berpengaruh terhadap kandungan bahan kering. Hal ini menunjukkan indikator bahwa mikroorganisme yang terdapat dalam MOL isi rumen mempunyai sifat yang diduga similar dengan lactobacillus sp. Begitu juga halnya dengan atau tanpa penambahan sumber karbohidrat juga tidak berpengaruh terhadap kandungan bahan kering.

Tabel 1, merupakan data rataan kandungan bahan kering, bahan organik dan protein kasar pelepah sawit fermentasi. Pada Tabel 1 memperlihatkan kandungan bahan kering tertinggi terdapat pada pelepah sawit yang difermentasi dengan menggunakan MOL isi rumen dan penambahan dedak sebagai sumber karbohidrat $(43,21 \%)$. Hal ini disebabkan tekstur fisik dedak lebih kasar dibanding dengan tepung tapioka sehingga penyerapan air selama proses fermentasi berlangsung diduga lebih sedikit sehingga kandungan bahan kering lebih tinggi. 
Tabel 1. Rataan kandungan Bahan kering, bahan organik, dan protein kasar pelepah sawit fermentasi

\begin{tabular}{|c|c|c|c|c|}
\hline \multirow[t]{2}{*}{ Faktor A } & \multicolumn{3}{|c|}{ FAKTOR B } & \multirow[t]{2}{*}{ TOTAL } \\
\hline & B1 & B2 & B3 & \\
\hline \multicolumn{5}{|c|}{ Bahan kering } \\
\hline A1 & 40,44 & 38,09 & 40,95 & 39,83 \\
\hline \multirow[t]{2}{*}{ A2 } & 37,50 & 43,21 & 36,74 & 39,15 \\
\hline & 38,97 & 40,65 & 38,85 & 39,49 \\
\hline \multicolumn{5}{|c|}{ Bahan Organik } \\
\hline A1 & 95,07 & 93,77 & 96,27 & 95,04 \\
\hline \multirow[t]{2}{*}{ A2 } & 95,14 & $\overline{93,46}$ & 96,26 & 94,95 \\
\hline & $95,11^{\mathrm{B}}$ & $93,62^{C}$ & $96,26^{\mathrm{A}}$ & 95,00 \\
\hline \multicolumn{5}{|c|}{ Protein Kasar } \\
\hline A1 & 5,17 & 6,70 & 2,94 & 4,94 \\
\hline A2 & 4,28 & 6,40 & 3,06 & 4,58 \\
\hline & 4,72 & 6,55 & 3,00 & 4,76 \\
\hline
\end{tabular}

Ket: Nilai rataan yang diikuti oleh superskrip $(\mathrm{A}, \mathrm{B}, \mathrm{C})$ pada baris yang sama menunjukan berbeda nyata $(\mathrm{P}<0,01)$.

$\mathrm{A} 1=$ Fermentasi dengan lactobacillus $s p$,

$A 2=$ Fermentasi dengan MOL isi rumen,

$\mathrm{B} 1=$ tanpa sumber karbohidrat ,

B2 = sumber karbohidrat dedak

B3 = sumber karbohidrat tapioka

Selain itu tepung tapioka termasuk ke dalam kelompok pati yang mempunyai daya absorbsi air. Air yang terserap dalam molekul menyebabkan granula pati mengembang sehingga air bebas berkurang (Richana dan Sunarti, 2004).

Proses fermentasi juga dapat mengakibatkan penurunan jumlah bahan kering. Data pada Tabel 1, terlihat kandungan bahan kering pelepah sawit yang difermentasi dengan menggunakan tepung tapioka sebagai sumber karbohidrat lebih rendah dibandingkan pelepah sawit yang difermentasi tanpa menggunakan sumber karbohidrat. Hal ini disebabkan penggunaan nutrien dari substrat oleh mikroba sebagai sumber karbon, nitrogen, dan mineral, serta dilepaskannya $\mathrm{CO}_{2}$ dan energi dalam bentuk panas yang menguap bersama partikel air. Molekul air tersebut terbentuk dari proses katabolisme yang merombak senyawa komplek menjadi bahan yang lebih sederhana (Zumael, 2009).

\section{Kandungan Bahan Organik}

Data pada Tabel 1, memperlihatkan tidak terdapat interaksi $(\mathrm{P}>0,05)$ antara jenis mikroorganisme dengan sumber karbohidrat, akan tetapi terdapat pengaruh yang nyata $(\mathrm{P}<0,05)$ pada perlakuan sumber karbohidrat. Uji lanjut dengan Duncan's Multiple Rate Test memperlihatkan fermentasi pelepah sawit dengan penambahan tapioka sebagai sumber karbohidrat mempunyai kandungan bahan organik nyata lebih tinggi dibandingan penggunaan dedak. Tinggi rendahnya kandungan organik pada perlakuan juga dimungkinkan oleh aktivitas mikroba pada proses fermentasi yang menyebabkan terjadinya pemecahan kandungan substrat sehingga mempermudah mikroorganisme yang ada untuk mencerna bahan organik, dan hasil fermentasi bahan organik melepaskan hasil fermentasi berupa gula, alkohol, dan asam asam amino dan juga disebabkan oleh aktifitas jasa renik sehingga terjadi perubahan yang mempengaruhi nilai gizi 
silase. Hal ini sesuai dengan pendapat Wilkinson (1988) yang menyatakan bahwa proses fermentasi yang dilakukan jasad renik sehingga terjadi perubahan yang mempengaruhi nilai gizi yaitu karbohidrat diubah menjadi alkohol, asam organik, air, dan $\mathrm{CO}_{2}$. Penggunaan molases juga merupakan sumber karbohidrat untuk bakteri asam laktat yang digunakan dalam fermentasi yang menyebabkan terjadi peningkatan kadar air yang mengakibatkan terjadinya kehilangan bahan organik.

\section{Kandungan Protein Kasar}

Hasil analisis keragaman menunjukkan tidak terdapat interaksi $(\mathrm{P}>0,05)$ antara jenis sumber mikroorganisme dengan penambahan sumber karbohidrat terlarut pada kandungan protein pelepah sawit fermentasi. Perlakuan sumber karbohidrat juga menunjukkan tidak berpengaruh $(\mathrm{P}>0,05)$ terhadap kandungan protein kasar substrat (Tabel 1). Kandungan protein kasar tertinggi ditunjukkan pada penambahan dedak halus. Hal ini disebabkan oleh kandungan protein kasar dedak halus yang cukup baik (10,8\%), di samping kaya kandungan vitamin dan mineral yang diperlukan oleh mikro organisme untuk tumbuh optimal dan beraktivitas dalam sintesis protein mikroba (Luh, 1991). Pada Tabel 1 terlihat kandungan protein kasar pada pelepah sawit fermentasi dengan penambahan sumber karbohidrat dari tepung tapioka lebih rendah jika dibandingkan dengan fermentasi tanpa penambahan karbohidrat. Hal ini disebabkan kandungan protein kasar pada dedak lebih tinggi dibandingkan kandungan protein kasar pada tepung tapioka, sehingga produk fermentasi dengan penambahan dedak mempunyai kandungan yang lebih tinggi di bandingkan penambahan tepung tapioka.

\begin{tabular}{|c|c|}
\hline hasilan & fermenta \\
\hline kan oleh & kemampuan \\
\hline upan & mikrobi \\
\hline
\end{tabular}

beradaptasi dengan substrat untuk digunakan sebagai nutrisi pertumbuhan dan perkembangan mikrobia (Zakaria et al., 2013). Mikrobia yang tidak mampu beradaptasi dan sulit mencerna substrat akan mati secara perlahan-lahan (Soeprijanto et al., 2008).

\section{KESIMPULAN}

Berdasarkan data penelitian ini dapat disimpulkan bahwa fermentasi pelepah sawit dengan penambahan sumber karbohidrat menggunakan dedak padi dapat meningkatkan kandungan protein dari $4,72 \%$ menjadi $6,55 \%$. Kandungan bahan organik hanya meningkat dari 95,11\% menjadi $96,26 \%$ pada fermentasi pelepah sawit menggunakan tepung tapioka sebagai sumber karbohidrat. Fermentasi dengan penambahan sumber karbohidrat berpengaruh terhadap kandungan bahan kering, bahan organik, dan protein kasar pelepah sawit fermentasi.

\section{UCAPAN TERIMA KASIH}

Ucapan terima kasih disampaikan kepada Bapak MENRISTEK DIKTI yang telah membantu dana penelitian, melalui pendanaan Insinas 2016.

\section{DAFTAR PUSTAKA}

AOAC, 1995. Official Methods of Analysis of The Association Agricultural Chemists. 14th Ed., Washington DC.

Astuti, T. 2012. Bioproses Optimalisasi Pemanfaatan Kulit Pisang dengan menggunakan Mikroorganisme Lokal (MOL) sebagai Pakan Ternak Ruminansia. Laporan Hibah Bersaing. Universitas Muara Bungo.

Astuti, T., Y. Amir, Irdawati and U. Santoso. 2016. Nutritional improvement of palm oil fronds for ruminant feed stuffs using a local biotechnological approach. Pak. J. Nutr., 15:450-454. 
Astuti. T., Y. S. Amir., G. Yelni and Isyaturriyadhah. 2014. The Result of Biotechnology by Local Microorganisms to Banana Peel on Rumen Fluid Characteristics as Ruminant Feed. Journal of Advanced Agricultural Technologies. 1(1):28-31.

Badan Ketahanan Pangan dan Penyuluhan Provinsi DIY, 2012.

Biyatmoko, D. 2013. Respons peningkatan nutrisi pelepah sawit fermentasi yang Diinokulasi dengan inokulum yang berbeda. Ziraa'ah. 36(1):20-24.

BPS, 2014. Statistik Perkebunan Indonesia 2013-2015 Kelapa Sawit. (Desember 2014).

Luh, B., 1991. Rice Utilization Vol II. Van Nostrand Reinhold, New York

NRC. 1994. Nutrient Requirements of Poultry. Ninth Revised Edition, National Academy Press. Washington, D. C.

Richana, N dan Sunarti, T.C., 2004. Karakterisasi Sifat Fisikokimia Tepung Umbi dan Tepung Pati dari Umbi Ganyong, Suweg, Ubi Kelapa, dan Gembili. Jurnal Pascapanen. 1(1): 29-37.

Simanihuruk K, Junjungan dan S.P. Ginting. 2008. Pemanfaatan pelepah kelapa sawit sebagai pakan basal kambing kacang fase pertumbuhan. Proseding Seminar Nasional Teknologi Peternakan dan Veteriner 2008. Hal 446-455
Simanihuruk. K., Junjungan dan A. Tarigan. 2007. Pemanfaatan pelepah kelapa sawit sebagai pakan basal kambing kacang fase pertumbuhan. Proseding Seminar Nasional Teknologi Peternakan dan Veteriner 2007. Hal 417-425

Soeprijanto., T. Ratnaningsih \& I. Prasetyaningrum. 2008. Biokonversi Selulose dari Limbah Tongkol Jagung Menjadi Glukosa Menggunakan Jamur Aspergilus Niger . JurnalPurifikasi. 9(2):1

Wajizah, S., Samadi., Usman, Y., Mariana, E., 2015. Evaluasi Nilai Nutrisi dan Kecernaan In Vitro Pelepah Kelapa Sawit (Oil Palm Fronds) yang Difermentasi Menggunakan Aspergillus niger dengan Penambahan Sumber Karbohidrat yang Berbeda. Agripet. 15(1): 13-19

Wina, E. 2005. Teknologi pemanfaatan mikroorganisme dalam pakan untuk meningkatkan produktivitas ternak ruminansia di Indonesia. Sebuah review. Wartazoa 15 (4): 173-186.

Zakaria. Y., C. I. Novita dan Samadi. 2013. Efektivitas fermentasi dengan sumber substrat yang berbeda terhadap kualitas jerami padi. Agripet. 13(1): 22-25

Zumael, Z. 2009. The Nutrient Enrichment of Biological Processing. Agricmed, Warsaw 